\title{
Spatial Analysis of Fire Service Station in Kano Metropolis, Nigeria
}

\author{
U. F. Isa ${ }^{1}$, M. A Liman ${ }^{2}$, M.U. Mohammed ${ }^{1}$, O. S Mathew ${ }^{3}$ and Y.R. Yayo ${ }^{1}$ \\ 1 Department of Geography, Bayero University, Kano \\ 2 Department of Urban and Regional Planning, Bayero University, Kano \\ 3Department of Transport Management Technology, Federal University of Technology, Minna
}

\begin{abstract}
The fire service mission is to assist the public in the protection of life and property by minimizing the impact of fire, medical emergencies, and potential disasters or events that affect communities and the environment.This study analyzed the spatial distribution, fire incidences and people's perception on the fire service station in Kano Metropolis. The data pertaining to the list of fire service station, number of fire personnel, equipments and fire incidences records were sourced from Kano State Fire Service Board. Global Positioning System (GPS) was used to measure the coordinates of the stations in the area. A structure questionnaire was administered to source people's view in the area. Nearest neighbour was used to determine the pattern of the distribution. ArcGIS 9.3 software was used to draw map of the distribution of the service stations, and table figure were used to present the survey result. From the finding, there are ten fire service stations in the area. The pattern of the distribution is dispersed at $95 \%$ level of significance. One and two kilometer buffer zones were generated and the result shows that only the old city of Kano is fully served while the other part of the metropolis is underserved. The ratio offirefighting personnel to population is approximately 1:5900 and the response time exceeds the minimum standard of 4 minute derive. Nearest neighborhood analysis has shown that the distribution of fire service stations is dispersed in the area. In addition most of the respondents ranked the service as poor. The paper recommended the need to have more and consider population and markets proximity in citing fire service station in the areas as one of the means for achieving better safety situations.
\end{abstract}

Keywords: Spatial Analysis,Fire service, Kano Metropolis, GIS

\section{INTRODUCTION}

Fire is defined as any instance of uncontrolled burning, including combustion explosions and fires out on arrival. Providing immediate and effective response to fires is important because emergency is a situation that poses an immediate risk to health, life, property or environment. Fire-Fighting Operations including rescue, fire suppression, and property conservation in buildings, enclosed structures, aircraft interiors, vehicles, vessels, aircraft, or like properties that are involved in an emergency situation (Jackson, 1999).

Excess density of population in city and itsalarming growth has attracted the attention of urban development agents to provide adequate and equitable services to all groups. In United State, in 2006 one person died in a fire accident approximately every 162 minutes on average, and one person was injured every 32 minutes (Karter and Stein, 2008). Each year, fire causes about 300,000 deaths globally and most of these occur in the home (Zhang et al, 2006).

Irwin (1997) reviewed Fire Service data and identified characteristics of fatal fire incidents. Some characteristics relate to features of the fire itself and may help to identify appropriate preventive strategies. Others point to vulnerable population groups. The spatial study is part of a broader epidemiological analysis which will build a dataset which will help to identify the relative importance of each characteristic in relation to different population groups.

Adekunle, Aderamo and Aina (2011) highlighted that inequality manifests in the form of unequal provision of social amenities within the districts of the local government. Provision of four social amenities was studied. These are educational, health, fire and market facilities. The Z-score variant was used to determine the spatial pattern of provision of the three facilities in the study area. The results of the analysis showed that inequalities exist in the provision of accessibility of social amenities in Ifelodun Local Government using educational, health, and fire and market facilities as criteria for measurement. In view of the fact that the federal, state and local governments provide most of these social amenities in Nigeria, the paper suggests that communities should supplement governments' efforts in order to improve the well-being of the people.

Habibi, Lotfi and Koohsari (2008) in their paper tried to integrate Analytical Hierarchy Process model and index overlay logic in GIS to present a model for fire station location planning. A comprehensive GIS-based 
fire stations location study can be the central component for a master plan for the station locations. This plan can show both the efficiency and deficiency of current fire stations coverage for a specified travel time and provide a model for future fire station location.

Podur et al. (2002) analyze spatial distribution of forest fires caused by lightning between 1976 and 1998 in Ontario region by using spatial data analysis techniques such as kernel density estimation, nearest neighbor and the $K$ - function to detect whether the patterns are clustered or random within the study area. More recently, Corcoran et al. (2007) apply spatial analysis methods to explore spatial dynamics and patterns of fire incidents in an area of South Wales. In a further research, Corcoran et al. (2007) apply spatio-temporal methods to understand the interaction between four principal fire incident categories, namely property, vehicle, secondary fires, and malicious false alarms. They employ simple line and circular plots for different periods of time (i.e., hourly, daily, and monthly) to investigate temporal patterns; cumulative sum technique coupled with the kernel density method to investigate spatial patterns; the co-map technique which illustrates the entire time period under study in a single visualization for the interaction of space and time. Corcoran et al. (2007) indicate that application of the spatio-temporal analysis techniques for fire incidents has potential to inform policy makers from both a reactive, resource-allocation perspective and a more proactive perspective, such as spatial targeting of preventive measures. Asgary et al. (2010) also applied temporal, spatial, and spatio-temporal analysis techniques and illustrate how the patterns of structural fire incidents in Toronto, Ontario, Canada from 2000 to 2006 vary with the time of the day, the day of the week, and the month of the year.

Although there is extensive research in fire management literature, the research on integration of spatial, temporal, and spatio-temporal data analysis techniques into fire clustering are quite limited and have started to gain attention recently. A better understanding of spatio-temporal patterns could provide vital information for effective fire management such as planning of fire prevention and response actions in terms of risk identification, resource targeting and routing of fire personnel and equipment, allocation of preventive measures, and policy evaluation with strategies for reducing fire related deaths, injuries and property losses.

Nisanci (2010) analysed that fire causes considerable losses that can be alleviated by taking appropriate precautions facilitated by sophisticated systems supported by information technologies. To eliminate or reduce the destructive effects of fires, fire risk management is a vital element for those who make the decisions (e.g. local governments and municipalities) concerning fire. For this purpose, geographical information systems (GIS) through effective spatial data storage and query can produce dynamic fire maps.

According to Mahmud and Indriasari (2009), the shape of total service area covered by emergency facilities such as fire stations is influenced by the road accessibility. The results reveals that coverage could be improved by providing better locations for fire stations even if the number of fire stations and their travel times are same as the existing situation. According to Envirolssues and Juan, the new fire station is expected to maintain or improve current service levels and response times for the primary response area and maintain or improve response times, system-wide (2008).

According to Habibi et al (2008), the main criteria for fire station location are distance among the stations; level of fire risk in the different parts of a city; accessibility; the coverage area; population; the size of plot and the directions of city expansion

For studies like this one with existing stations to consider, defining demand begins with an assessment of the effective response area for each of those stations, usually by using time or distance limits. Most researchers chose to create the response area as a straight-line or Euclidean buffer rather than a network buffer because of computation time (Liu et al. 2006) or because the necessary network data was unavailable (Murray and Tong 2009). In a thorough comparison of the two methods, Euclidean buffers were found to over-estimate service areas (Gutierrez and Garcia-Palomares 2008). This was especially true in locations with a low density of stations or with sparse road networks, situations common to rural environments. In attempts to address this issue, some researchers have focused on non-circular service areas. For example, Matisziw and Murray (2009) studied the Planar MCLP with continuous demand and irregular service areas based on road networks. Their study focused exclusively on urban environments, however.

Applications of GIS to fire and other emergency mapping and management have been successful in many developed countries (Murray et al, 2005). GIS allows fire fighter personnel to make plans effectively for emergency response, determine mitigation priorities, analyze historical events, and predict future events; it helps fire officers to determine potential incident sites and facilitates to explore the relationship between incident and land use (Ajemirokun, et al, 2006).

Urban Kano has been experiencing a population growth, since the creation of the state in 1967. As such there is increase in residential, commercial, industrial and institutional land uses leading to urban expansion. The simultaneous increase in population and settlement expansion of the town has a direct effect on the increase in emergencies.

Fire services in Nigeria are not well equipped with modern and automated information system.This is one of the basic problems militating against the effective and prevention, detection and control of fire. Many 
variables, including staffing, training and equipment, are considered in determining whether coverage is adequate (NFPA, 2010). One of the most crucial variables is response time, specifically the time it takes to get from the fire station to the fire incidence point (NFPA, 2010). Ideally, officials would place a fully staffed and equipped fire station on every corner. However this is mostly impossible because of limited resources, so there is a need to assess and address inadequacies in fire coverage with available resources. In addition to average travel time, obtained by measuring travel times between fire stations and actual incidents, travel times between fire stations and potential fire hazard areas (such as hospitals, schools, chemical plants, musing homes, and high rise buildings), are important as measures of fire department performance and in deployment analysis.

According to Human right watch (2005) as British sought colonial expansion; they established colonial decentralized urban amenities, with a varied composition which depended on location. In the modern world and Nigeria in particular, there is no way efficient fire service will be guaranteed without considering the relationship between location and pattern of distribution of fire service stations, demography and size of the community.Identifying such importance, this research found it worthwhile to investigate the distribution pattern of the stations in Metropolitan Kano. This is because life and property protection would not be guaranteed unless fire fighters and policing are adequately provided.

Kano metropolis is one of the most densely populated cities in Nigeria. Like all major cities in developing nations, the cities battle with many emergencies and other serious situation due to influx of people. According the 2006 Nigeria National Census the city has more than two million traders (NPC, 2006).

In Nigeria, the role of geography is under estimated in the fire service, which is to a large extent responsible for the inability of the fire fighters to prevent and control the alarming increase fire and other emergencies in the society (NFPA, 2010). It was established that a large proportion of the men of the fire service can hardly ascertain the areas under the jurisdiction of their stations or define the shortest route from their stations to be specific. Fire service has been unable to meet the safety and protect need of the local community in Nigeria (Human Right Watch, 2005). In the same vein, Nigerian fire fighters are not particularly effective in foreseeing where and when specific future emergency will take place. Therefore, geography plays an important role in protection of life and properties.

There are numbers of Fire Service Stations in Kano Metropolis but it has not been established whether this Fire Service Stations and facilities are adequate and equally distributed. Kano State Fire Service admitted that there is no available map showing the distribution of Fire Service Stations in Kano Metropolis. Thus, the map produced at the end of this study will be of vital importance to both planners and managers. And this is one of the goals of the current study.

\section{MATERIAL AND METHODS}

The paper uses of both primary and secondary data that were gathered through pre-field work and detailed field survey. The list and addresses of the Fire Service Stations, and other records were collected from the State Fire Service Headquarter this served as a guide to identify and locate all the Fire Stations.Hand held Global Positioning System, GPS was used to take the co-ordinates of all the fire service stations in the area. A database was created in Microsoft Excel (2007) and used to record the coordinates, names, locations, addresses, number of staffs and facilities. The excel data were saved as dbf and the imported to the Arcmap environment of ArcGIS 9.3 for the analysis. Nearest neighbour analysis was done to determine the pattern of the distribution. Buffer analysis was performed to determine the served and underserved areas.

A survey of people views on the fire service was carried out using structure questionnaire. The Sampling was done using Krejcie and Morgan 1970 at the marginal error 0.05 and $95 \%$ confidence level. Based on the procedure the sampling population is 384 , as such 384 copies of the questionnaires were administered of which 365 were retrieved. Availability sampling technique was adapted due to lack of sampling frame. The results of the questionnaire survey were analysed using Statistical Package for the social Science (SPSS) software. Frequency distribution and cross tabulation were carried out to come up with tables for some parameters and charts for others depending on the appropriateness. Some aspect of information gathered from interviewing the personnel of the Kano State Fire Service was also included in the non-spatial aspect related discussions.

\section{STUDY AREA}

The study area, Kano metropolis lies between latitude $11^{0} 05^{\prime} \mathrm{N}$ to $12^{0} 07^{\prime} \mathrm{N}$ and longitude $8^{0} 23^{\prime} \mathrm{E}$ to $8^{0} 47^{\prime}$ E and altitude 472 meters above sea level. Kano Metropolis bordered by Minjibir LGA on the North East and Gezawa LGA to the East, while Dawakin Kudu LGA to the South East, Madobi and Tofa LGAs to the South West. 


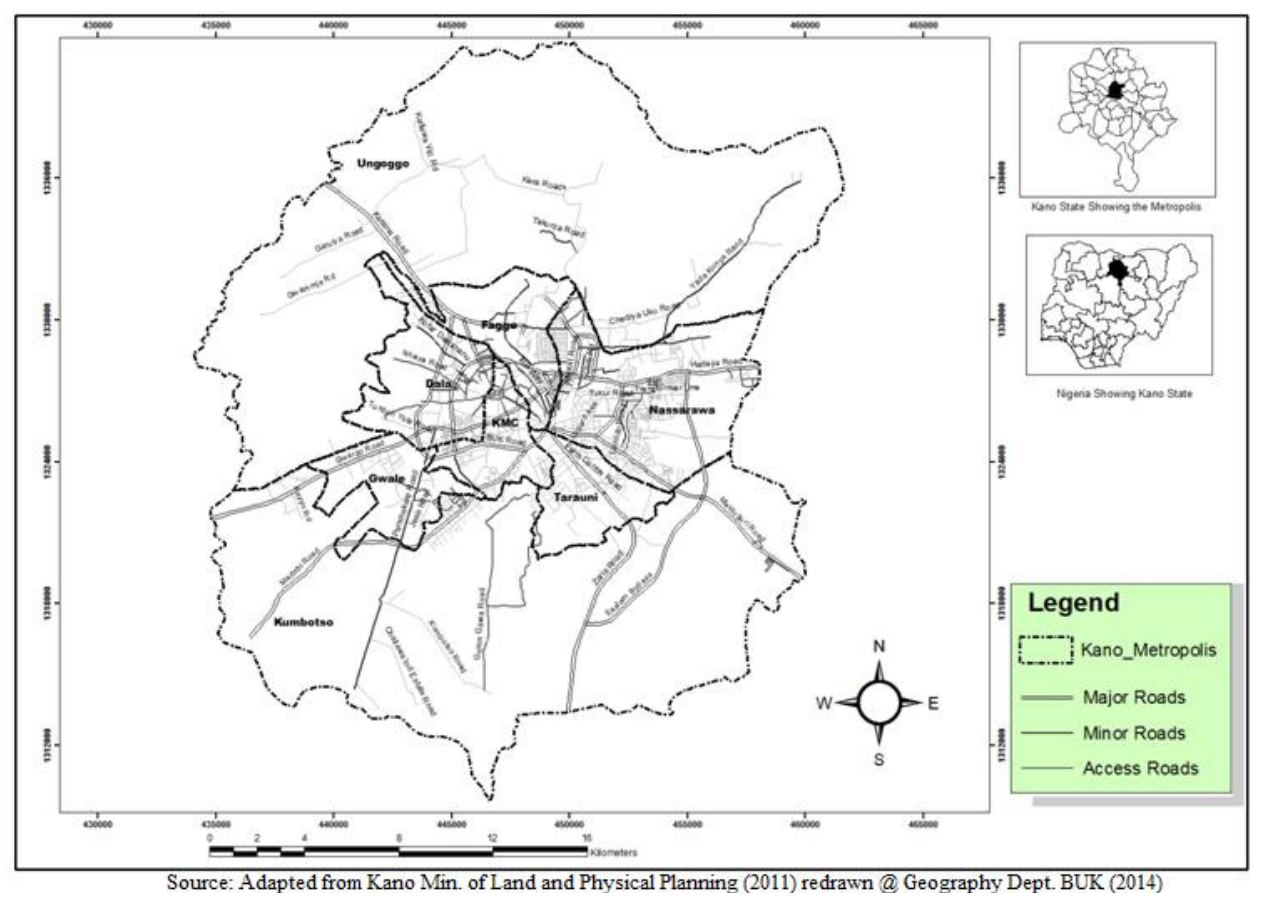

Figure 1: Kano Metropolis

Kano metropolis is the second largest industrial and commercial centre in Nigeria after Lagos and it is experience rapid population growth rate, the population of metropolis at (year 2000) is 1.6million (Maiwada 2000). In 2003 the population raised to 2.3 million (approximately) and in 2006 to 2.8 million. The area covers almost 499square kilometers. With a population density of about 1000 inhabitants per $\mathrm{km}^{2}$ within the Kano closed-settled zone compared to the national average of 267 inhabitants per $\mathrm{km}^{2}$. It is also one of the most crowded. The city also has a large migrant worker population which has been increasing at the rate of 30 to 40 per cent per annum (UNDP 2004). It has also through time become a cosmopolitan city with all the ethnic groups across the city. Kano Metropolis comprises the six core urban local government (Dala, Fagge, Gwale, Kano Municipal, Nassarawa and Tarauni) and two peri-urban local governments (Kumbotso and Ungogo).

Residential uses dominate most part of the study area, however other land uses such as commercial, institutional, and educational are all located within areas. Dakata, Sharada and Bompaifunctioned as industrial layout. Industries such as steel rolling, packaging, beverages processing etc are found in this area. Commercial activities happened to be growing very fast in the area. There are many big and international markets such as SabonGari, KantinKwari, Singer market, Dawanau and Yankaba markets in the area.

\subsection{Inventory}

\section{RESULTS AND DISCUSSION}

Based on the research findings, there wereten (10) fire service stations in metropolitan Kano, out of which two are located at Gwale Local government (Aminu Kano Way and Sharada Phase III), two located at Kano Municipal local government (Jakara and KofarNassarawa), and two located at Nassarawa local government (Dakata and AuduBakoSecteriat). Dala local government (KurnaAsabe), Tarauni local government (Court Road), Fagge local government (SabonGari Market), and Ungogo local government (RijiyarZaki)have on station each (figure 2). 


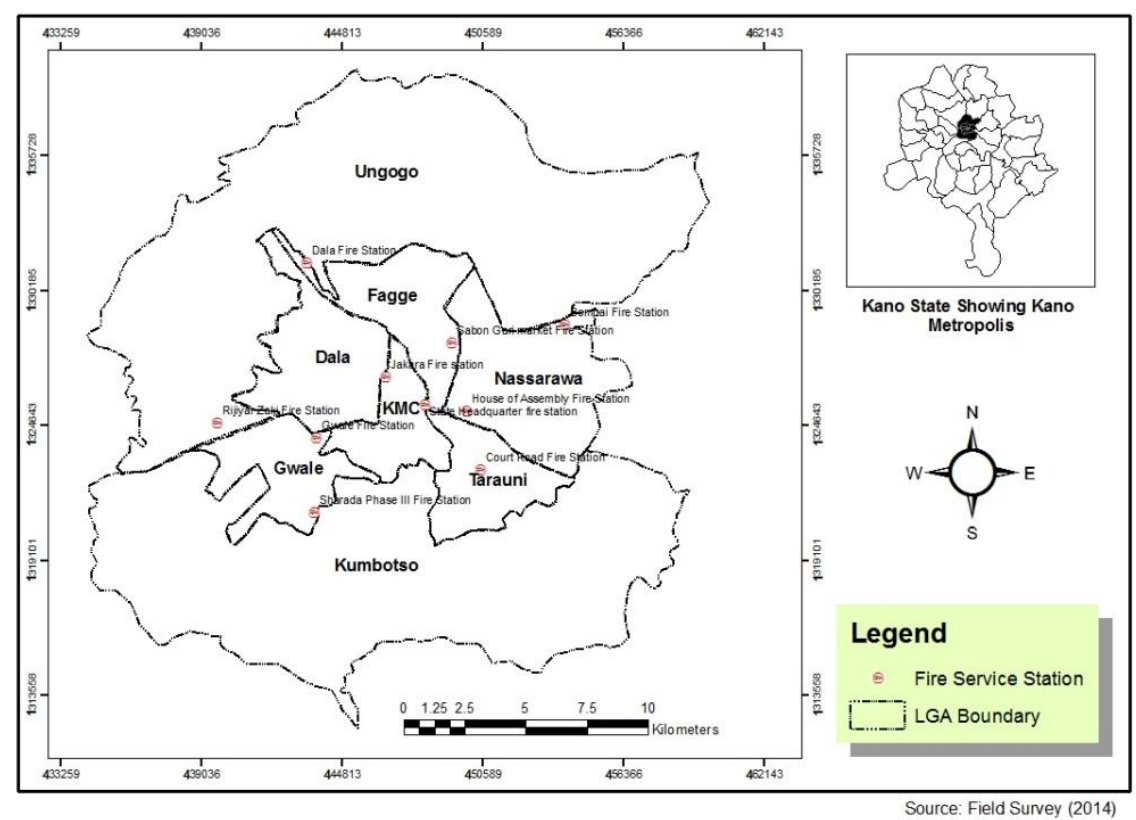

Figure 2: Inventory of Fire Service Stations in Kano Metropolis

\subsection{Distribution of Fire Fighting Personnel in Kano Metropolis}

Thepersonnel in each of the 10 fire service stations were presented table 1. Man power is not evenly distributed with the eight Kano metropolitan local governments, about $38.4 \%$ of man power is found in Kano municipal, while the remaining portion is shared by the seven other Local Government Areas. Nassarawa local government has the highest population among the Eight Local Government Areas is very much underserved. Dala Local Government is the second highest in term of population has just $6.9 \%$ of the total man power, Kumbotso which is the seventh in term of population has $0.0 \%$ of man power.

Table 1: Distribution of Fire Personnel in Kano Metropolis

\begin{tabular}{|l|l|l|l|l|l|}
\hline \multirow{2}{*}{ S/N } & \multirow{2}{*}{ LGA } & \multicolumn{2}{|l|}{ No. of Personnel } & \multirow{2}{*}{ Population } & $\begin{array}{l}\text { Personnel } \\
\text { Population Ratio }\end{array}$ \\
\cline { 3 - 4 } & & F & $\mathbf{\%}$ & & $1: 12,690$ \\
\hline 1 & Dala & 33 & 6.9 & 418,759 & $1: 4,021$ \\
\hline 2 & Gwale & 89 & 18.7 & 357,827 & $1: 8,400$ \\
\hline 3 & Nassarawa & 71 & 14.9 & 596,411 & $1: 2,029$ \\
\hline 4 & Kano Municipal & 183 & 38.4 & 371,243 & $1: 5,042$ \\
\hline 5 & Tarauni & 44 & 9.2 & 221,844 & $1: 6,253$ \\
\hline 6 & Ungogo & 24 & 5.2 & 365,737 & - \\
\hline 7 & Fagge & 32 & 6.7 & 200,095 & $\mathbf{1 : 5 9 2 5}$ \\
\hline 8 & Kumbotso & 0 & 0 & 294,391 & $\mathbf{2 , 8 2 6 , 3 0 7}$ \\
\hline & TOTAL & $\mathbf{4 7 7}$ & $\mathbf{1 0 0}$ & $\mathbf{2}$ & \multicolumn{2}{l}{} \\
\hline
\end{tabular}

Source: Kano State Fire Service, 2013.

From the result it had been observed that on average each fire service personnel approximately six thousand person in Kano Metropolis. However the ratio varies between the administrative local governments. Kumbotso has no fire service station at all, while Dala and Ungogo have the least number of personnel with ratio 1:15,293and 1:12,690 respectively. Kano Municipal where the head quarter is located has the lowest ratio of one fire officer serving atleast two thousand people (table 1).

\subsection{Fire Service Facilities in Kano Metropolis}

There common fire Service facilities in the area are fire engines and ambulance and the ambulance, the number of facilities for the fire service stations are in table 2.

From table 2 there are eleven (11) fire engines that serve all the Kano metropolis, out of which only the headquarter has just two (2) and all other fire stations have oneeach. It is also noticed that out of all the ten (10) fire service station in Kano metropolis only two stations which are the headquarter having ( 2 ambulance) and RijiyarZaki fire station ( 1 ambulance. As such the area is greatly under served. Other facilities that are used in 
fighting fire and other emergencies present in all the stations in the study area includes; hand control branch, metal branch, dribbly hose, section hose, ladder and rope line dividing breach.

Table 2: Distribution of Fire Fighting Facilities in Kano Metropolis

\begin{tabular}{|c|l|l|l|l|}
\hline S/N & Name of Station & LGA & $\begin{array}{l}\text { No } \\
\text { Ambulance }\end{array}$ & $\begin{array}{l}\text { No of } \\
\text { Fire Engine }\end{array}$ \\
\hline 1. & Gwale & Gwale & Nil & 1 \\
\hline 2. & Jakara & Kano Municipal & Nil & 1 \\
\hline 3. & Dala & Dala & Nil & 1 \\
\hline 4. & State Headquarter & Kano Municipal & 2 & 2 \\
\hline 5. & House of Assembly & Nassarawa & Nil & 1 \\
\hline 6. & Court Road & Tarauni & Nil & 1 \\
\hline 7. & Sharada Phase III & Gwale & Nil & 1 \\
\hline 8. & Bompai & Nassarawa & Nil & 1 \\
\hline 9. & SabonGari Market & Fagge & Nil & 1 \\
\hline 10. & RijiyarZaki & Ungogo & 1 & 1 \\
\hline & Total & & $\mathbf{3}$ & $\mathbf{1 1}$ \\
\hline
\end{tabular}

Source: Kano State Fire Service, 2013

\subsection{The buffer Zone Analysis of Fire service Stations}

There is no standard distance for citing fire station in the country. But the distance 1000 meters $(1 \mathrm{~km})$ and 2000 meters $(2 \mathrm{~km})$ radius were done on the map to see analyse the accessibility to fire stations. This shows that one has to travel more than a $\mathrm{km}$ before reaching a fire station. The result shows almost allthe areas of the metropolitan Kano are underserved, considering $1 \mathrm{~km}$ buffer. Areas that are outside the old city are not fully served, considering the both 1 and $2 \mathrm{~km}$ buffer. In addition only $7 \%\left(31.89 \mathrm{~km}^{2}\right)$ and $17 \%\left(74.89 \mathrm{~km}^{2}\right)$ of the study area were served considering the 1 and $2 \mathrm{~km}$ buffers respectively (figure 3 ).

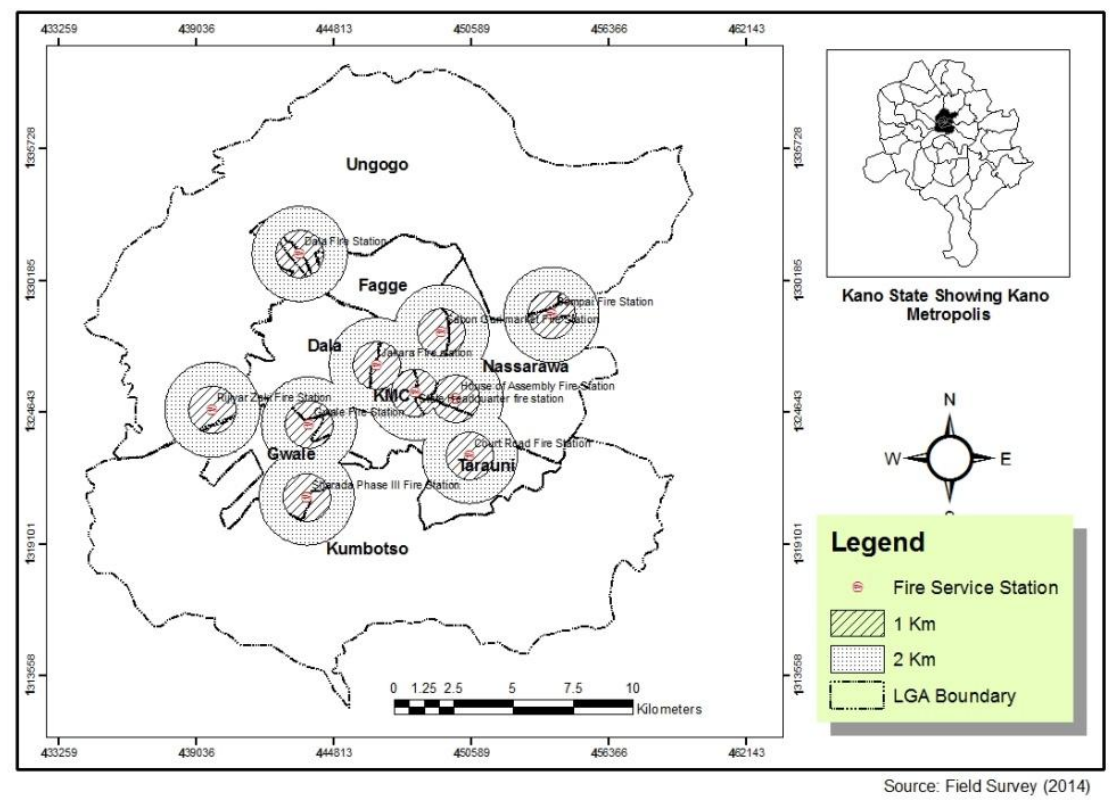

Figure 3: Buffer Analysis of Fire Service Stations in Kano Metropolis

\subsection{Spatial Pattern of Fire Service Stations in Kano Metropolitan}

One of the most important goals of geographic studies is identifying the pattern distribution of a events, activities $r$ phenomenon in a space. The assumption is things (even, phenomena or activities) are randomly distributed. There many methods of pattern analysis, one of which is nearest neighbour. This paper examined the pattern of the distribution of fire service station in Kano Metropolis using the nearest neighbour analysis. The 
results of the Nearest Neighborhood analysis using normal Z-score for the distribution is 7.63 and the nearest neighbour index (Rn-value) is 2.26 indicating that the pattern observed is neither clustered nor random but perfectly dispersed in nature. In addition the probability (p-value) is less than 0.01 indicating there is significant different between the distribution of fire service station and the pattern random pattern and there is less $1 \%$ likelihood the pattern observed occur by chance.

Furthermore the result confirmed the earlier low ranking of proximity of Fire Stations. The dispersed pattern observed further confirms the absence of a definite spatial planning and technical threshold standard to guide Fire Service Station locations.

\subsection{Fire, False and Rescue Calls from 2008 to 2012}

Data on the total number of fire calls, false calls, and rescue calls of each year from 2008 to 2012 in Kano metropolis where sourced from the fire service headquarter at KofarNassarawa, Kano.The result had shown that a total of 4,343 fire calls, 1,062 false calls, and 11,535 rescue calls were received between 2008 and 2012. The year 2010 had the highest number of fire calls of nine hundred and Seventy Four (974), Three hundred and sixty six (366) false calls and three thousand One hundred and Seventy Three (3173) rescue calls (figure 4).

Between 2008 and 2012 Kano State Fire Service received a total of four thousand three hundred and forty Three (4343) fire distress calls which it promptly responded to, even though there was One thousand and Sixty Two (1062) false calls and Eleven Thousand five Hundred and Thirty Five (11535) rescue calls. False alarms waste valuable man power and resources which may be needed desperately at a real emergency. Anytime fire fighter ride trucks, they are at risk. The frequency of rescue calls is higher than fire and false calls, and also the frequency of false calls is lower than the fire and rescue calls in every year.

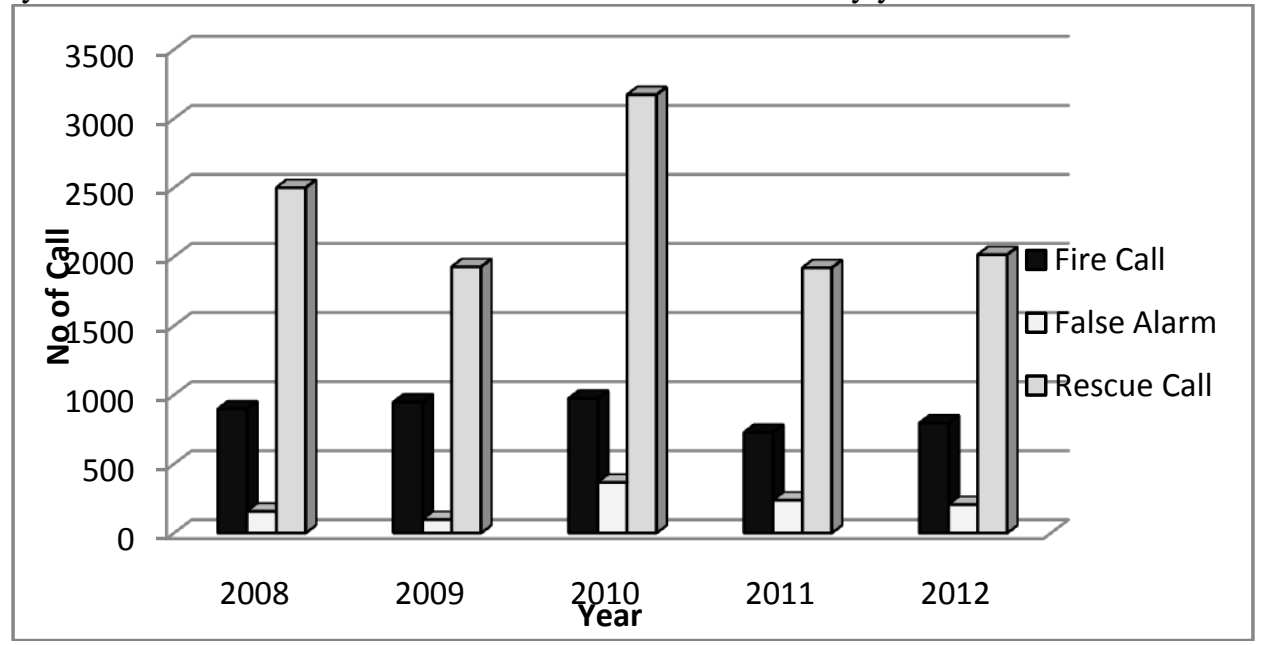

Figure 4: Fire, False and Rescue Calls (2008-2012) in the Kano Metropolis

\subsection{Lives Lost and Lives Saved from Fire in Metropolitan Kano}

Figure 5shows the number of live lost and live saved caused by fire and other emergency from 2008 to 2012 in metropolitan Kano. A total of nine Hundred and Thirty Six (936) live lost and Sixteen Thousand and Twenty Nine (16029) live saved was recorded by Kano State Fire Service. The pattern displayed in the figure shows that the number of live lost and live saved is generally higher in 2010. This may be as result of the highest fire outbreak and other emergency recorded in the year. Also from the table it is very clear that 2011 have the lowest frequency of live lost and live saved recorded.

The result obtained from Kano state fire Service the total number of live saved is much higher than the total number of live lost (table above). 2010 recorded the highest number of live saved and live lost; these may be a result of the highest number of fire outbreak recorded by the Kano State Fire Service. The frequency at which the rate of live saved is much higher than that of live lost in every year particularly in 2010. 


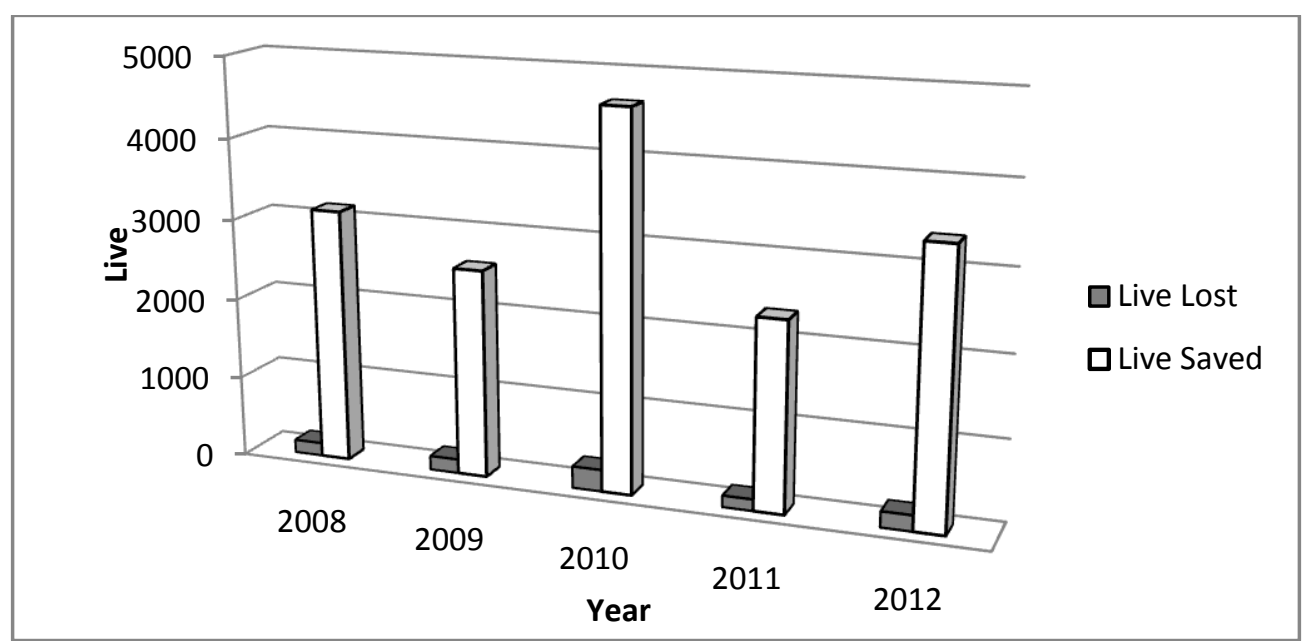

Figure 5: Lives Lost and Saved between 2008 and 2012 in the Kano Metropolis

The Fire Service should educate the public to take precautions to prevent potentially harmful fires and be educated about surviving them. It is a proactive method of reducing emergency and damage caused by them.

\subsection{Estimated Properties Lost and Saved}

The data obtained from Kano State fire service shows that properties worth approximately 11.5 billion were saved from fire in the five years under study. 2008 has the highest properties, followed by 2009, 2012, 2010 and 2011 in decreasing order (figure 6).

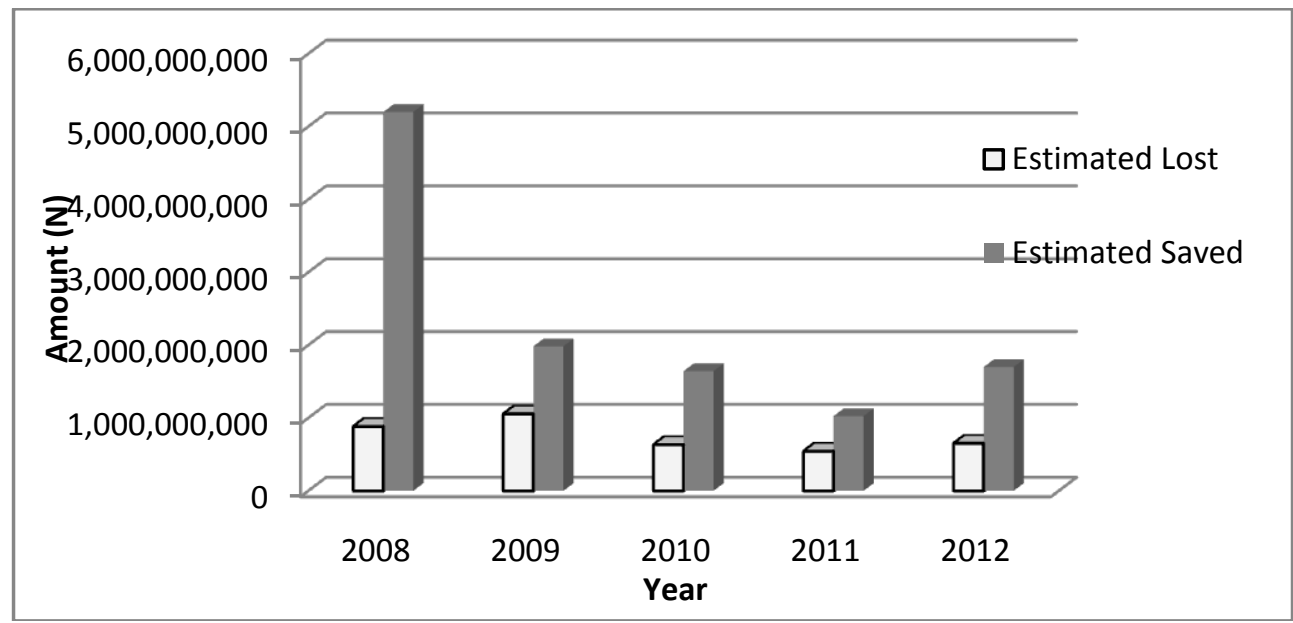

Figure 6: Properties Lost and Saved (2008-2012) in the Kano Metropolis

\subsection{People Knowledge on Fire Service Station}

Issues related to knowledge on fire service station were among the findings during the questionnaire survey. The respondents perception the function of fire service station were presented in figure 7 


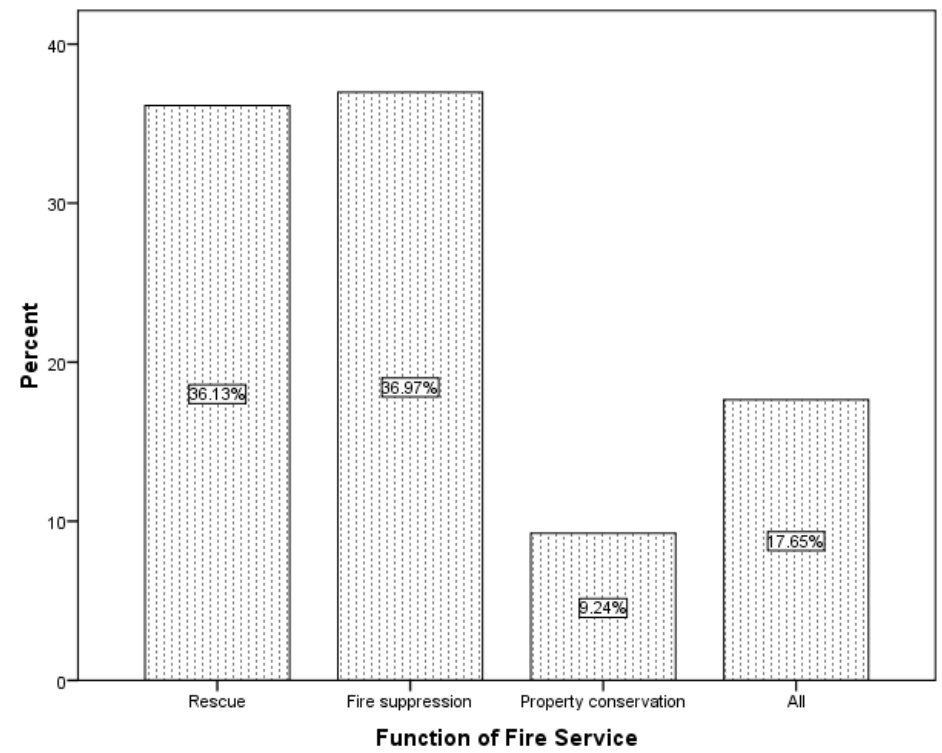

Figure 7: Functions of the Fire Service Station

Figure 7 shows the function of Fire Service Stations in Kano metropolis. Almost equal numbers of the respondents were of the view that rescue or fire suppression is the main function of fire service in metropolitan Kano, each account for more than one third of the response. On other hand only few (9\%) believed the function of fire service station as property conservation. About $18 \%$ however agreed that the three are function of fire service station

\subsection{Causes of Fire Incidence}

The result of the causes of fire incidences are presented in figure 9

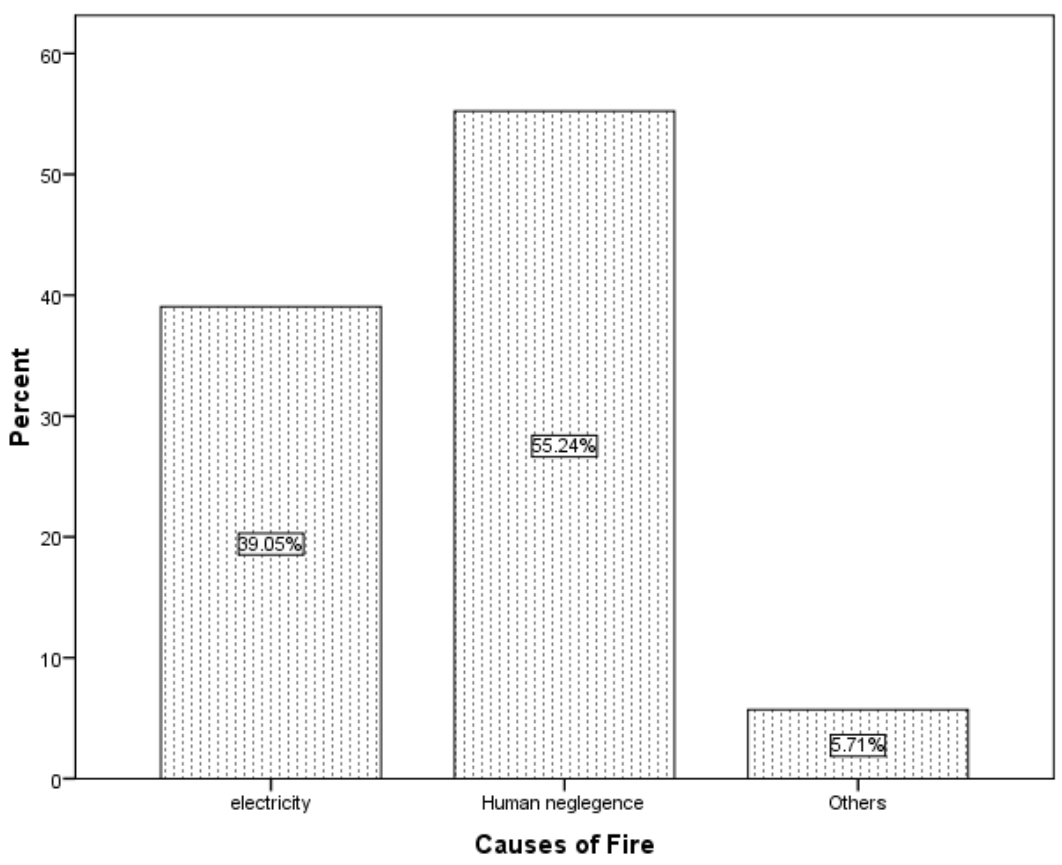

Figure 8: Causes of Fire Outbreak in Kano Metropolis

Figure 8 shows the causes of fire outbreak in metropolitan Kano. More than half of the respondents are of the view that human negligence is the main causes of fire outbreak in the study area, followed by those attributing the incidence to electricity (39\%). Very few believed that fire is cause by others factors $(5.7 \%)$ which may include gas cooker, children etc. 


\subsection{Response Time in the Case of Fire Incidence}

Response time is one of the major considerations in case of fire incidence, the amount live and property to rescue depends on response. Thus the study looked at the responds time in the area with a view to see the effectiveness of the fire servicing stations in the area. The response time were presented in table

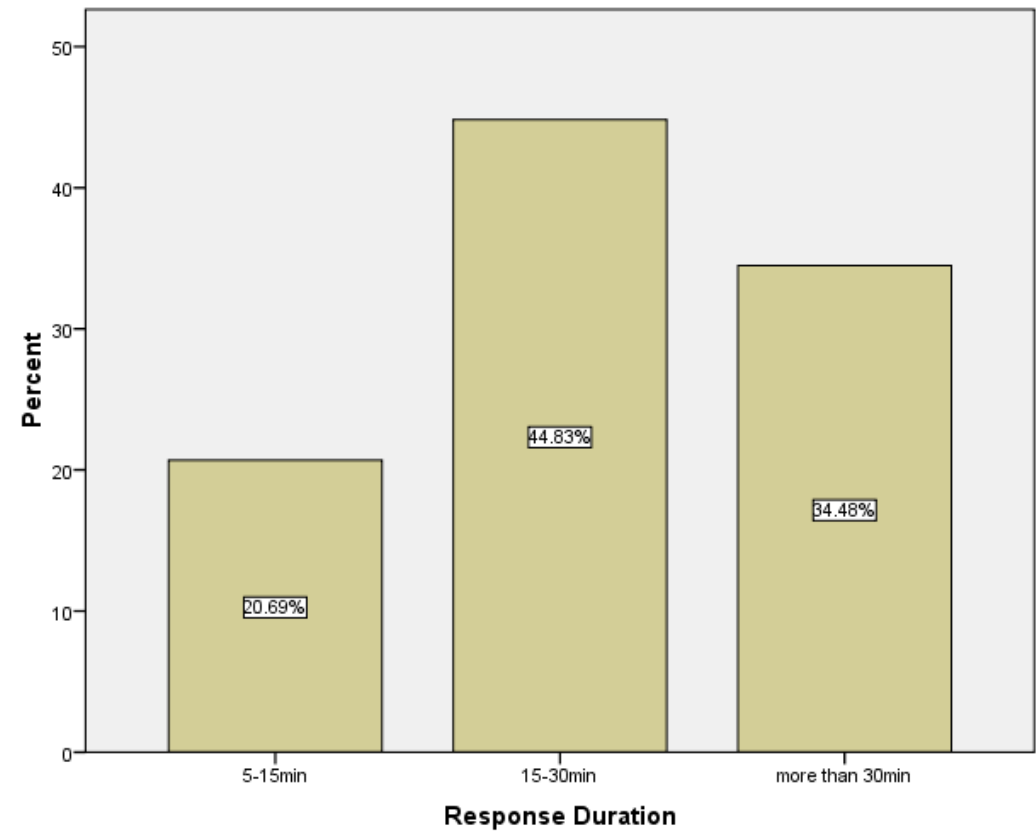

Figure 9: Fire Service Stations' Response in KanoMetropolis

As can be observed in figure 9 most of the respondents believed that response duration of thee fire servicing station in the area is between 15-30 minute. Almost one third were of the opinion that response time is more than thirty minute. Very few (20\%) said the response time is 5-15 minute. On average the response is poor and exceed the minimum standards of four minute

\section{5. CONCLUSION}

This paper had attempted to analyze the spatial distribution of fire service stations in Kano metropolis. Even though loss (of both life and property) had and is being saved by the fire service station, the challenge is still there. This work found the situation very worrisome. It is clear the stations were not enough, poorly equipped (in both men and machine) and the service rendered is poor. It is on this basis that the paper makes the following recommendations:

Population distribution should be a considerable factor in the distribution of fire service stations and fire personnel.There is need for deployment of more fire personnel and erection of fire stations in the areas that are under served most urgently (e.g.Kumbotso local government area).Kano being densely populated requires effective coverage by strategically located fire stations that should fill the existing gaps in the provision of fire facilities and in future must to pace with the urban expansion in both time and space.

\section{REFERENCE}

[1] Aderamo A.J. (2011). Spatial inequalities in accessibility to social amenities in developing countries: A Case from Nigeria. Australian Journal of Basic and Applied Sciences, 5(6), 316-322.

[2] Asgary, A., Ghaffari, A., Levy, J. (2010). Spatial and temporal analyses of structural fire incidents and their causes: A case of Toronto Canada. Fire Safety Journal, 45pp 44-57.

[3] Badri, M.A., Mortagy, A.K., Colonel A.A. (1998). A multiobjective model for locating fire stations. Eur. J. Oper. Res. 110(2):243-260.

[4] Burrough, P.A. (1998). Principles of Geographic Information System. New York, Oxford University.

[5] Chen, C. and Ren A.(2003). Optimization of fire station locations using computer. J T singhuaUniv (Sci\& Tech). 43(10), pp. 1390-1393.

[6] Corcoran, J., Higgs, G., Brunsdon, C., Ware, A. (2007). The use of comaps to explore the spatial and temporal dynamics of fire incidents: a case study in South Wales, UK, The Professional Geographer, 59pp521-536. 
[7] Corcoran, J., Higgs, G., Brunsdon, C., Ware, A., Norman, P.(2007). The use of spatial analytical techniques to explore patterns of fire incidence: a South Wales case study. Computers, environments and urban systems, 31 pp623-647.

[8] Davies, B.P. (1968). Social Needs and Resources in Local Services. Michael Joseph, London.

[9] Diwekar, U. (2003).Introduction to Applied Optimization. Kluwer, Norwell, MA.

[10] Drezner, Z. (1995). Facility Location: A Survey of Applications and Methods. Springer, New York.

[11] Geis, D.E. (2000). By Design: The Disaster Resistant and Quality of The Life Community. Geis DesignResearch Associates, Published jointly by the American Society of Civil Engineers (ASCE) \& The Natural Hazards and Research Applications Information Center at the University of Colorado.

[12] Goldberg, J.B. (2004). Operations research models for the deployment of emergency services vehicles. EMS Management Journal1(1):20-39.

[13] Habibi, K., Lotfi, S. and Koohsari, M.J. (2008). Spatial Analysis of urban fire station locations by integrating AHP model and IO logic using GIS: A case study of zone 6 of Tehran.Journal of applied science 8(19):3302-3315,2008. Asian Network of Scientific information.

[14] Irwin, K. (1997). Domestic fire hazard in New Zealand Fire engineering research report.Christchurch, University of Canterbury.

[15] Jackson L.L.(1999). An evaluation of the need for proximity protective clothing for Aircraft firefightingStrategic Management of Change. An applied research project submitted to the National Fire Academy as part of the Executive Fire Officer Program. Retrieved from www.usfa.fema.gov/

[16] KarterMJ and Stein JGP (2008). U.S. Fire Department Profile Through 2007, Fire Analysis and Research Division National Fire Protection Association,http://www.doi.idaho.gov/SFM/FDProfile_2007.pdf.

[17] Knox, P. L., (1978). The intraurban ecology of primary medical care: patterns of accessibility and their policy implications. Environment and Planning Fire Protection Agency, NFPA. National Fire Protection Handbook, 10 415-435. Boston; National Fire ProtectionAgency.

[18] Maiwada, A.D. (2000). Disappearing open spaces in Kano metropolis. Proceedings of thenational workshop on land administration and development in Northern Nigeria. Departmentof Geography, Bayero University Kano, Nigeria.

[19] National Fire Protection Association, NFPA(2010). Standard for the organization and deployment of fire suppression operations, emergency medical operations and special operations to the public by volunteer fire departments.

[20] Neufert, P., Baiche, B., \&Walliman, N. (2000). Neufert, Architects' Data, 3rd Ed. Blackwell Science Publisher, UK.

[21] Nisanci, R. (2010): GIS based fire analysis and production of fire-risk maps: The Trabzonexperience. Scientific Research and Essays, Vol. 5(9), pp. 970-977, 4 May, 2010 Available online at ISSN 1992-2248 (C) 2010 Academic Journals.

[22] Pacione, M. (1989), Access to urban services - the case of secondary schools in Glasgow. Scottish Geographical Magazine 105 12-18.

[23] Pinch, S. (1984)Inequality in pre-school provision: a geographical perspective,In Public Service Provision and Urban Development Eds. Kirby, A., Knox, P.and PinchS. Croom Helm, London Pp. 231282 ,

[24] Sahin, G. andSural, H. (2007). A review of hierarchical facility location models. Comput. Operation Research Journal, Science direct 34(8):2310-2331.

[25] Toregas, C., Swain, R., ReVelle, C and Bergman, L. (1971). The location of emergency service facilities. Comput. Operation Research Journal, Science direct19(6):1363-1373.

[26] Toregas, C., and ReVelle, C. (1973). Binary logic solutions to a class of location problem. Geographical Anaysisl, 5(2):145-155.

[27] Tzeng G.H., Chen, Y.W. (1999). The optimal location of airport fire stations: A fuzzy multi-objective programming and revised genetic algorithm approach. Transportation Planning Tech. 23(1):37-55.

[28] Zhang, G., Lee, A.H., Lee H.C. and Clinton M. (2006). Fire safety among the elderly in Western Australia, Fire Safety Journal. 41: 57-61. 